\title{
Gambaran prevalensi malaria pada anak SD YAPIS 2 di Desa Maro Kecamatan Merauke Kabupaten Merauke Papua
}

\author{
${ }^{1}$ Sharky D. Daysema \\ ${ }^{2}$ Sarah M. Warouw \\ ${ }^{2}$ Johnny Rompis
}

\author{
${ }^{1}$ Kandidat Skripsi Fakultas Kedokteran Universitas Sam Ratulangi Manado \\ ${ }^{2}$ Bagian Pediatri Fakultas Kedokteran Universitas Sam Ratulangai Manado \\ Email: Dean.daysemaa@gmail.com
}

\begin{abstract}
Malaria is an infectious disease caused by Plasmodia which invade erythrocytes and is diagnosed by the asexual forms in blood. WHO estimated 3,4 billion people were at risk of malaria and 207 million cases of malaria occurred globally in 2012 and 627.000 deaths. Papua Province is one of the provinces in Indonesia that has high malaria rate. This study aimed to determine the prevalence of malaria parasites in students of SD Yapis 2, Merauke, Papua. This was a descriptive observational study with a cross-sectional approach. Samples were obtained by using simple random sampling associated with active detection by using microscopic examination and the Rapid Diagnostic test. There were 100 children aged between 6-13 years old. The results showed that SD Yapis 2 was categorized as a prevalent medium area with a PR 15\%. There were 15\% children infected by P. falciparum species. Conclusion: SD Yapis 2 was categorized as a medium prevalent area with Plasmodium falciparum species.
\end{abstract}

Keywords: malaria, plasmodium falciparum, microscopic examination, rapid diagnostic tests

\begin{abstract}
Abstrak: Malaria adalah penyakit infeksi parasit yang disebabkan oleh Plasmodium yang menyerang eritrosit dan ditandai dengan ditemukannya bentuk aseksual dalam darah. WHO memperkirakan 3,4 milliar orang beresiko terkena malaria dan 207 juta kasus terjadi pada tahun 2012 dan 627.000 kematian. Provinsi Papua merupakan salah satu provinsi di Indonesia yang memiliki angka kasus malaria cukup tinggi. Penelitian ini bertujuan untuk mengetahui prevalensi parasit malaria pada anak SD Yapis 2, Merauke, Papua. Penelitian ini menggunakan metode observasional deskriptif dengan pendekatan potong lintang. Sampel diperoleh dengan metode simple random sampling serta dilakukan secara active detection dengan pemeriksaan mikroskopik dan penggunaan Rapid Diagnostic Tests. Sampel diperoleh sebanyak 100 anak usia 6-13 tahun. Hasil penelitian memperlihatkan bahwa SD Yapis 2 termasuk medium prevalent area dengan PR 15\%. Jenis Plasmodium yang ditemukan yaitu P. falciparum menginfeksi anak-anak sebesar 15\%. Simpulan: SD Yapis 2 dapat di kategorikan daerah prevalensi sedang (medium prevalent area) dengan spesies malaria P. falciparum.
\end{abstract}

Kata kunci: malaria, plasmodium falciparum, pemeriksaan mikroskopis, tes diagnosis cepat

Malaria adalah penyakit infeksi parasit yang disebabkan oleh Plasmodium yang menyerang eritrosit dan di tandai dengan ditemukannya bentuk aseksual dalam darah. ${ }^{1}$ Terdapat 4 Plasmodium penyebab penyakit malaria yaitu Plasmodium falciparum penyebab malaria tropika, Plasmodium vivax penyebab malaria tertiana, Plasmodium malariae penyebab malaria quartana dan Plasmodium ovale penyebab malaria ovale. ${ }^{2}$ Infeksi malaria memberikan gejala berupa demam, menggigil, anemia dan splenomegali. Gejala lain yang mungkin timbul ialah sakit kepala, mual atau muntah dan diare serta nyeri otot atau pegal-pegal pada orang dewasa. Infeksi malaria dapat berlangsung akut maupun kronik, tanpa komplikasi 
ataupun mengalami komplikasi sistemik yang dikenal dengan malaria berat., ${ }^{1,2}$

Menurut WHO, terdapat 97 negara dan wilayah yang merupakan tempat berpindahnya penularan malaria dan 7 negara yang masih dalam proses pencegahan fase reintroduksi, sehingga total terdapat 104 negara di mana malaria dianggapendemik. Secara global, diperkirakan 3,4 milliar orang beresiko terkena malaria dan WHO memperkirakan 207 juta kasus terjadi pada tahun 2012 dan 627.000 kematian. $^{3}$ Di Indonesia, berdasarkan laporan Riskesdas 2010, selama tahun 2009/2010 terdapat lima provinsi dengan kasus malaria tertinggi yaitu Papua (261,5\%o), Papua Barat (253,4\%o), Nusa Tenggara Timur (117,5\%), Maluku Utara (103,2\%o) dan Kepulauan Bangka Belitung (91,9\%o), sedangkan provinsi dengan kasus malaria terendah adalah Bali $(3,4 \%){ }^{4}{ }^{4}$

Provinsi Papua merupakan salah satu provinsi di Indonesia yang memiliki angka kasus malaria cukup tinggi. Pada tahun 2013, kabupaten merauke dengan AMI (Annual Malaria Incidence)/angka kesakitan malaria sebesar $54 \%$, Dari 10.535 kasus yang diambil sediaan darahnya dan dilakukan pemeriksaan mikroskopik dan pemeriksaan RDT terdapat 3.530 sediaan yang positif malaria. Laporan tertinggi kejadian malaria di puskesmas Mopah Baru, puskesmas Rimba Jaya, dan puskesmas Kuprik. ${ }^{5}$

Diagnosis yang tepat dan cepat serta terapi yang akurat adalah kunci untuk meminimalkan mordibitas dan mortalitas akibat malaria. ${ }^{6,7}$ WHO merekomendasikan manajemen kasus berdasarkan pada parasite-based diagnosis untuk semua kasus kecuali pada anak-anak di daerah dengan transmisi tinggi dan kurang sumber daya. ${ }^{8} \mathrm{Di}$ Indonesia diagnosis malaria di tegakkan dengan pemeriksaan mikroskopik dan pemeriksan RDT. ${ }^{9,10}$ Penggunaan RDT membantu dalam menegakkan parasitebase diagnosis di daerah di mana kualitas mikroskopiknya yang baik kurang tersedia. ${ }^{8}$ Untuk mengetahui tingkat kesakitan suatu daerah di gunakan parameter Parasite Rate (PR), parameter ini di dapat dengan membuat sediaan darah tebal dan ditentukan presentase sediaan yang mengandung parasit, dengan diketahuinya Parasit rate maka dapat di tentukan daerah tersebut masuk dalam daerah LPA (Low Prevalent Area), MPA (Medium Prevalent Area), dan HPA (High Prevalent Area). ${ }^{11}$

Berdasarkan latar belakang tersebut, peneliti tertarik untuk membahas tentang gambaran prevalensi malaria pada anak Sekolah Dasar Yapis 2, di Desa Maro, Kecamatan Merauke, Kabupaten Merauke, Papua dengan pemeriksaan mikroskopis dan RDT yang membantu menegakkan diagnosis pasti malaria.

\section{METODE PENELITIAN}

Penelitian ini menggunakan metode deskriptif dengan pendekatan potong lintang. Metode pengambilan sampel yang digunakan ialah Simple Random Sampling. Penelitian ini dilakukan secara Active detection dengan pemeriksaan mikroskopik sediaan darah tipis serta sediaan darah tebal dan penggunaan Rapid Diagnostic Tests.

\section{HASIL DAN BAHASAN \\ Kelompok Umur}

Berdasarkan kelompok umur (tabel 1) terdapat pada anak umur 6-11 yang terinfeksi malaria namun tidak mengeluhkan gejala trias malaria yang meliputi menggigil, demam dan berkeringat. Umur anak yang terinfeksi yaitu anak umur 6-8 tahun dengan jumlah sebanyak 8 anak; umur 9-10 tahun sebanyak 4 anak; dan umur 11-13 tahun sebanyak 3 anak yang positif malaria. Hasil yang dilaporkan Puskesmas Mopah Baru kepada Dinas Kesehatan Kabupaten Merauke, pada anak umur 1-4 tahun terdapat 200 anak, 5-9 tahun terdapat 137 dan anak 10-14 tahun 90 anak yang positif malaria.

\section{Jenis Kelamin}

Berdasarkan jenis kelamin (tabel 1) terdapat jumlah anak laki-laki sebanyak 46 anak dan yang terinfeksi sebanyak 7 anak. Jumlah anak perempuan sebanyak 54 anak 
Jurnal e-Clinic (eCl), Volume 4, Nomor 1, Januari-Juni 2016

dan yang terinfeksi sebanyak 8 anak.

Tabel 1. Karakteristik Responden

\begin{tabular}{|c|c|c|c|c|c|}
\hline \multicolumn{6}{|c|}{ Hasil P.Mikroskopis } \\
\hline \multirow[t]{2}{*}{ Jenis kelamin } & & \multicolumn{3}{|c|}{ Umur Responden } & Total \\
\hline & & $6-8$ & $9-10$ & $11-13$ & \\
\hline \multirow[t]{3}{*}{ Laki - laki } & negatif & 16 & 13 & 10 & 39 \\
\hline & Positif & 4 & 1 & 2 & 7 \\
\hline & Total & 20 & 14 & 12 & 46 \\
\hline \multirow[t]{3}{*}{ Perempuan } & negatif & 22 & 14 & 10 & 46 \\
\hline & positif & 4 & 3 & 1 & 8 \\
\hline & Total & 26 & 17 & 11 & 54 \\
\hline
\end{tabular}

Tabel 2. Karakteristik Responden

\begin{tabular}{llcc}
\hline & & \multicolumn{2}{c}{$\begin{array}{c}\text { Hasil RDT } \\
\text { Responden }\end{array}$} \\
\cline { 3 - 4 } & & Negatif & Total \\
\cline { 3 - 4 } Hasil & Negatif & 85 & 85 \\
Mikroskopik & Positif & 15 & 15 \\
Responden & & 100 & 100 \\
Total & & & \\
\hline
\end{tabular}

\section{Jenis Plasmodium}

Jenis Plasmodium yang ditemukan pada penelitian ini ialah P. falciparum; P. vivax, P. malariae dan P. ovale tidak ditemukan (tabel 1). Menurut data dari Dinas Kesehatan Kabupaten Merauke selama tahun 2013 terdapat malaria klinis sebanyak 4.036 kasus sedangkan jumlah yang terinfeksi malaria terdapat 714 orang, dengan penjabaran sebagai berikut Plasmodium falciparum terdapat 542 orang, Plasmodium vivax 172 orang, untuk Plasmodium malariae, Plasmodium ovale dan mixed tidak menunjukkan hasil positif atau tidak ada yang terinfeksi Plasmodium tersebut sesuai hasil laporan kejadian malaria dari Dinas Kesehatan Kabupaten Merauke yang berasal dari Puskesmas Mopah Baru.

\section{Pemeriksaan darah mikroskopis dan RDT}

Didasari penelitian selama bulan Desember 2014 - Januari 2015 di peroleh sebanyak 100 sampel. Pada pemeriksaan mikroskopis hanya di peroleh Plasmodium falciparum sebanyak 15 sampel. Hasil yang didapatkan ialah Plasmodium falciparum berbentuk ring (cincin), jumlah kepadatan parasit 2-5 dalam 100 LPB. Banyak penelitian tentang metode pemeriksaan laboratorium dalam diagnostik malaria yang lebih baik dari yang sudah ada, namun sampai saat ini, pemeriksaan mikroskopis masih pilihan utama dan merupakan standar baku diagnosis malaria yang efektif.

Tabel 3. Hasil pemeriksaan darah mikroskopis dan RDT

\begin{tabular}{|c|c|c|c|c|c|}
\hline \multicolumn{6}{|c|}{ Hasil P.Mikroskopis } \\
\hline \multirow[t]{2}{*}{ Jenis kelamin } & & \multicolumn{3}{|c|}{ Umur Responden } & Total \\
\hline & & $6-8$ & $9-10$ & $11-13$ & \\
\hline \multirow[t]{2}{*}{ Laki - laki } & negatif & 20 & 14 & 12 & 46 \\
\hline & Total & 20 & 14 & 12 & 46 \\
\hline \multirow[t]{2}{*}{ Perempuan } & negatif & 26 & 17 & 11 & 54 \\
\hline & Total & 26 & 17 & 11 & 54 \\
\hline
\end{tabular}

Kelebihan pemeriksaan mikroskopik ialah dapat menghitung jumlah kepadatan parasit dan dapat melihat bentuk parasit yang utuh dan morfologinya sempurna serta dapat menentukan jenis Plasmodium, stadium Plasmodium dan kepadatan parasit. Kepadatan parasit dapat membantu dalam menentukan prognosis dan pemeriksaan berkelanjutan dapat membantu dalam menentukan respon parasit terhadap terapi. Kekurangan yang dimiliki pemeriksaan mikroskopik diantaranya diperlukan mikroskop berkualitas dan sumber listrik serta tenaga laboratorik yang ahli dan berpengalaman. Pemeriksaan ini juga menghabiskan waktu yang cukup lama dan juga kualitas hapusan darah memengaruhi hasil pemeriksaan.

Pada pemeriksaan RDT yang menggunakan merk Mono dengan 2 antibodi spesifik terhadap antigen P.f HRPII (Protein P.falciparum) dan pLDH (Parasite lactale dehydrogenase) mendapatkan hasil negatif pada seluruh responden yang mengikuti pemeriksaan. Perbedaaan interpretasi hasil ini dapat terjadi di karenakan RDT memiliki sensitifitas $90 \%$ dalam mendeteksi infeksi P. falciparum jika jumlah parasit $>100 /$ $\mu \mathrm{L}$ darah. Jika jumlah Parasit <100/ 
$\mu \mathrm{L}$ darah, maka sensitifitasnya menurun. Disamping itu mungkin juga dapat di sebabkan karena jumlah parasit yang relatif rendah, dan pada uji imunokromatografi positif tidak selalu menujukkan infeksi malaria aktif.

Pemeriksaan RDT memiliki kelebihan bila dibandingkan dengan pemeriksaan mikroskopis adalah RDT dapat dilakukan dengan cepat serta prosedur diagnosis yang sederhana dan mudah penyimpulannya. RDT juga dapat dilakukan oleh individu dengan pelatihan minimal.

Pemeriksaan RDT memiliki beberapa kekurangan diantaranya hasil positif palsu dan negatif palsu pada beberapa studi kasus. Hasil positif palsu terjadi karena reaksi silang dengan faktor rheumatoid di darah. Hasil negatif palsu yang jarang disebabkan oleh delesi atau mutasi gen hrp2. Kelamahan lain dari pemeriksaan RDT terbatas hanya pada P.falciparum dan P.vivax dan juga tidak dapat digunakan untuk mengetahui kepadatan parasit dalam darah. Kualitas alat diagnostik RDT sangat dipengaruhi juga oleh transportasi dan penyimpanan alat diagnostik. Kelembapan dan temperatur yang tinggi dapat dengan cepat merusak reagen.

Perbedaan hasil dari Pemeriksaaan mikroskopis dan pemeriksaaan RDT disebabkan karena antigen P.f HRP-II (Protein P. falciparum) adalah sebuah protein larut air yang di hasilkan oleh tahap aseksual dan gametosit P. falciparum dan pLDH (Parasite lactale dehydrogenase) adalah enzim glikolitik soluble yang dihasilkan oleh tahap aseksual dan seksual dari parasite. Tes pLDH ini di buat untuk mendeteksi parasitemia $>100$ hingga 200 parasit $/ \mu \mathrm{L}$ dan beberapa dari tes P.f HRPII dikatakan untuk mendeteksi parasitemia aseksual $>40$ parasit $/ \mu L$. Pada pemeriksaan mikroskopik ditemukan Plasmodium falciparum berbentuk ring (cincin), jumlah kepadatan parasit 2-5 dalam 100 LPB sehingga pada anak yang terdeteksi malaria belum menunjukkan gejala. Hal ini di karenakan plasmodium yang terdeteksi masih dalam bentuk tropozoit yang belum melalui sebuah siklus sempurna dari siklus ekso eritrositer.

Oleh karena perbedaan hasil yang cukup signifikan untuk menindaklanjuti hasil ini, perlu dilakukan pemeriksaan lanjutan, yaitu dengan metode PCR.

\section{Parasit Rate}

SD Yapis 2 dapat di kategorikan sebagai medium prevalent area(daerah prevalensi sedang).

Persentase Parasit rate :

$$
\begin{aligned}
& \frac{\text { Jumlah sediaan darah positif }}{\text { Jumlah sediaan darah yang diperiksa }} \times 100 \% \\
& =\frac{15}{100} \times 100 \%=15 \%
\end{aligned}
$$

\section{SIMPULAN}

SD Yapis 2 dapat di kategorikan daerah prevalensi sedang (medium prevalent area) dan spesies malaria yang ditemukan ialah P. falciparum.

\section{DAFTAR PUSTAKA}

1. Harijanto PN, malaria. Buku ajar ilmu penyakit dalam Jilid III edisi V. Jakarta: EGC;2009.h. 2813.

2. Depkes RI. Pedoman Penyelenggaraan System Kewaspadaan Dini (SKD) dan Penanggulangan Kejadian Luar Biasa (KLB), Jakarta: 2007. Tersedia dari URL:

http://www.hukor.depkes.go.id/up_pro d_kepmenkes/KMK/No.0042/Pedoma

n Penyelenggaraan Sistem Kewaspadaan Dini (SKD) dan Penanggulangan KLB Malaria.pdf

3. World Health Organization [internet]. World malaria report 2013 . c2013.[di unduh tanggal 22 november 2014] Tersedia dari URL: http://www.who.int/malaria/publicati ons/world_malaria_report_2013/wmr 2013_no_profiles.pdf?ua $=1$

4. Depkes RI. Riskesdas. 2010 (diunduh 22 november 2014). Tersedia dari URL: http://www.litbang.depkes.go.id/sites/ download/buku_laporan/lapnas_riske sdas2010/Laporan_riskesdas_2010.pd $\mathrm{f}$

5. Dinas Kesehatan Kab.Merauke. Laporan bulanan penemuan dan pengobatan malaria Kabupaten Merauke. Merauke: Dinkes, 2013. 
6. Kakkilaya BS. Rapid Diagnosis of Malaria. LabMed. 2003;8(34):602-60.

7. Barrwell JW, Causer L, Bloland BP. Strategies for improved diagnostics for malaria, including rapid diagnosis. 2003. Tersedia dari URL: http://www.tropike.net/review//03032 4-Malaria15/article.pdf

8. WHO. Malaria Rapid Diagnostic Test Performance: Executive Summary. 2008. Tersedia dari URL: http://apps.who.int/tdr/newsevents/ news/pdf/executive-summarymalariaRDTs.pdf

9. Direktorat Jenderal PPPL. Pedoman Penatalaksanaan Kasus Malaria di Indonesia. Departemen Kesehatan RI. 2008. Tersedia dari URL : http://www.pppl.depkes.go.id/asset/d ownload/Pedoman_Penatalaksana_Ka sus_Malaria_di_Indonesia.pdf

10. Kusuma W, Lestari W, Herawati S, Yasa I. Pemeriksaan mikroskop dan tes diagnostik cepat dalam menegakkan diagnosis malaria [Skripsi]. Denpasar: Bagian/SMF Patologi Klinik Fakultas Kedokteran Universitas Udayana/ Rumah Sakit Umum Pusat Sanglah Denpasar; 2014.

11. Depkes RI. Pedoman Surveilans Malaria, Departemen Kesehatan RI, Jakarta. 2007. Tersedia dari URL : http://www.hukor.depkes.go.id/up_pr od_kepmenkes/KMK/No.275/Pedom anSurveilans Malaria.pdf 